\title{
TINJAUAN YURIDIS TERHADAP PELAKSANA PENGAWASAN PILKADA BERDASARKAN UNDANG-UNDANG NOMOR 8 TAHUN 2015 DALAM MEWUJUDKAN DEMOKRASI DI DAERAH
}

\author{
DESSY AGUSTINA HARAHAP1 \\ 1Universitas Medan Area \\ 1Dessyagustina86@yahoo.com
}

\begin{abstract}
ABSTRAK
Pilkada atau pemilihan kepala daerah merupakan sarana pelaksanaan kedaulatan rakyat di daerah. Hal ini merupakan bagian dari perkembangan sistem penyelenggaraan pemerintahan Negara Republik Indonesia yang mengalami berbagai perubahan. Perubahan yang dimaksud adalah prinsip otonomi yang berarti keleluasaan untuk mengatur daerahnya sendiri pada setiap daerah. Pemilihan kepala daerah (Pilkada) dilakukan secara langsung oleh penduduk daerah administratif setempat yang memenuhi syarat. Pemilihan kepala daerah dilakukan satu paket bersama dengan wakil kepala daerah.Pengawas pilkada memiliki kewenangan menyelesaikan sengketa pemilihan, prosesnya dilakukan dengan mempertemukan para pihak, agar diperoleh kesepakatan melalui musyawarah. Hal ini disebutkan pada Pasal 143 Undang-undang No. 1 Tahun 2015 tentang Penetapan Peraturan Pemerintah Pengganti Undang-undang No. 1 Tahun 2014 tentang Pemilihan Gubernur, Bupati dan Wali Kota menjadi Undang-undang sebagaimana telah diubah dengan Undang-undang No. 8 Tahun 2015. Jenis penelitian ini adalah penelitian normatif. Penelitian normatif yang dimaksud yaitu penelitian yang objek kajiannya meliputi norma atau kaidah dasar, asas-asas hukum, peraturan perundang-undangan, perbandingan hukum, doktrin, serta yurisprudensi.
\end{abstract}

Kata Kunci : Bawaslu, Pengawasan, Pilkada

ABSTRACT
The elections or the local election is a means of implementing the people's sovereignty in the area. This is part of the development of the system of governance of the Republic of Indonesia, which had several changes. Changes in question is the principle of autonomy means freedom to manage their own regions in each region. The local elections (elections) is done directly by the local administrative area residents are eligible. The local elections conducted one package along with the deputy head of the region.Election supervisor has the authority to resolve election disputes, the process is carried out by bringing the parties together, in order to obtain an agreement by consensus. It is mentioned in Article 143 of Law No. 1 Year 2015 about concerning the Stipulation of Government Regulation in lieu of Law No. 1 Year 2014 regarding the Election of governors, regents and mayor became Act as amended by Law No. 8 Year 2015.This research is a normative study. Normative research in question is the research object of study includes basic norms or rules, principles of law, legislation, comparative law, doctrine and jurisprudence.

Keywords : Bawaslu, Monitoring, Regional Election

\section{Pendahuluan}

Pengaturan mekanisme pengisian jabatan kepala daerah dalam Undang-undang Nomor 15 Tahun 2011 tentang Penyelenggara Pemilu, tidak lagi menggunakan istilah pemilihan umum kepala daerah atau pemilukada, tetapi "pemilihan Gubernur, pemilihan Bupati, atau pemilihan Walikota". Demikian halnya, yang digunakan dalam Undang-undang Nomor 22 Tahun 2014 tentang Pemilihan Gubernur, Bupati, dan Walikota yang daya berlakunya hanya satu hari, serta merta dicabut oleh Perppu Nomor 1 Tahun 2014, meskipun tata 
cara pemilihannya tidak lagi secara langsung, namum isitilah yang digunakan sama. ${ }^{1}$

Istilah yang sama kembali digunakan dalam Undang-undang Nomor 8 Tahun 2015 tentang Perubahan Undangundang Nomor 1 Tahun 2015 tentang Pemilihan Gubernur, Bupati, dan Walikota. Dalam Undang-undang Nomor 8 Tahun 2015, pemilihan kepala daerah kembali ditetapkan dengan berpasangan. Pemilihan Gubernur dan Wakil Gubernur, Bupati dan Wakil Bupati, serta Walikota dan Wakil Walikota yang selanjutnya disebut "Pemilihan" adalah pelaksanaan kedaulatan rakyat di wilayah provinsi dan kabupaten/kota untuk memilih Gubernur dan Wakil Gubernur, Bupati dan Wakil Bupati, serta Walikota dan Wakil Walikota secara langsung dan demokratis. ${ }^{2}$ Pemilihan dilaksanakan setiap 5 (lima) tahun sekali secara serentak di seluruh wilayah Negara Kesatuan Republik Indonesia. Perubahan Undang-undang Nomor 1 Tahun 2015 tentang Pemilihan Gubernur, Bupati, dan Walikota menjadi Undang-undang Nomor 8 Tahun 2015, pemilihan kepala daerah kembali ditetapkan dengan berpasangan. Pemilihan Gubernur dan Wakil Gubernur, Bupati dan Wakil Bupati, serta Walikota dan Wakil Walikota yang selanjutnya disebut "Pemilihan" adalah pelaksanaan kedaulatan rakyat di wilayah provinsi dan kabupaten/kota untuk memilih Gubernur dan Wakil Gubernur, Bupati dan Wakil Bupati, serta Walikota dan Wakil Walikota secara langsung dan demokratis. ${ }^{3}$ Pemilihan dilaksanakan setiap 5 (lima) tahun sekali secara serentak di seluruh wilayah Negara Kesatuan Republik Indonesia.

Untuk menuju penyelenggaraan pemilihan serentak secara nasional pada tahun 2027, ditempuh melalui tujuh tahapan. Tahap pertama pemilihan serentak pada bulan Desember 2015, untuk kepala daerah yang masa jabatannya berakhir pada tahun 2015 dan bulan Januari sampai dengan bulan Juni tahun 2016. Tahap kedua, pemilihan serentak bulan Februari tahun 2017 untuk

\footnotetext{
${ }^{1}$ Heru Widodo, Hukum Acara Perselisihan Hasil Pilkada Serentak Di Mahkamah Konstitusi, (Jakarta, Sinar Grafika), Halaman13

${ }^{2}$ Ibid,

${ }^{3}$ Ibid, Halaman 15.
}

kepala daerah yang masa jabatannya berakhir pada bulan Juli sampai dengan bulan Desember 2016 dan yang masa jabatannya berakhir pada tahun 2017.

Tahap ketiga, pemilihan serentak bulan Juni tahun 2018 untuk kepala daerah yang masa jabatannya berakhir pada tahun 2018 dan tahun 2019. Tahap keempat, pemilihan serentak tahun 2020 untuk Gubernur dan Wakil Gubernur, Bupati dan Wakil Bupati, serta Walikota dan Wakil Walikota hasil pemilihan tahun 2015. Tahap kelima, pemilihan serentak pada tahun 2022 untuk Gubernur dan Wakil Gubernur, Bupati dan Wakil Bupati, serta Walikota dan Wakil Walikota hasil pemilihan tahun 2017.

Tahap keenam, pemilihan serentak pada tahun 2023 untuk Gubernur dan Wakil Gubernur, Bupati dan Wakil Bupati, serta Walikota dan Wakil Walikota hasil pemilihan tahun 2018. Tahap ketujuh, pemilihan serentak pada tahun 2027 untuk Gubernur dan Wakil Gubernur, Bupati dan Wakil Bupati, serta Walikota dan Wakil Walikota di seluruh wilayah Negara Kesatuan Republik Indonesia.

Dengan penyelenggaraan pemilihan serentak secara bertahap, terdapat daerah yang periodisasi masa jabatannya sudah berakhir namum belum diselenggarakan pemilihan, sehingga terjadi kekosongan jabatan kepala daerah. Untuk mengisi kekosongan jabatan Gubernur, diangkat penjabat Gubernur yang berasal dari jabatan pimpinan tinggi madya sampai dengan pelantikan Gubernur. Untuk mengisi kekosongan jabatan Buapati/Walikota, diangkat pejabat Bupati/Walikota yang berasal dari jabatan pimpinan tinggi pratama sampai dengan pelantikan Bupati/Walikota. ${ }^{4}$ Agar pemilihan kepala daerah sesuai dengan peraturan perundang-undangan yang berlaku, maka harus ada badan yang mengawasi pelaksanaan pemilihan kepala daerah.

Berdasarkan latar belakang yang penulis uraikan di atas, penulis ingin mengkaji lebih lanjut mengenai pelaksanapengawasan Pemilihan Kepala Daerah, dengan menyusun penelitian berjudul "Tinjauan Yuridis Terhadap Pelaksana Pengawasan PILKADA

${ }^{4}$ Ibid, Halaman 15 
Berdasarkan Undang-undang Nomor 8 Tahun 2015 dalam Mewujudkan Demokrasi di Daerah.

\section{Rumusan Masalah}

Berdasarkan latar belakang yang telah diuraikan di atas, maka permasalahan yang diangkat oleh penulis dalam penelitian ini dirumuskan adalah sebagai berikut :

1. Bagaimana Undang-undang Nomor 8 Tahun 2015 mengatur tentang pelaksanaan pengawasan Pilkada?

2. Bagaimana tugas dan fungsi Badan Pengawas Pemilihan Umum dalam penyelenggaraan Pilkada?

\section{Metode Penelitian}

\section{A. Jenis Dan Sifat Penelitian}

Jenis penelitian ini adalah penelitian normatif. Penelitian normatif yang dimaksud yaitu penelitian yang objek kajiannya meliputi norma atau kaidah dasar, asas-asas hukum, peraturan perundang-undangan, perbandingan hukum, doktrin, serta yurisprudensi. ${ }^{5}$ Sifat penelitian ini adalah deskriptif analitis yaitu menggambarkan atau mendeskripsikan ketentuan peraturan perundang-undangan yang berkaitan dengan pelaksana pengawasan Pemilihan Kepala Daerah secara analitis. ${ }^{6}$ Yang mengarah pada penelitian yuridis normatif yaitu suatu penelitian studi kepustakaan terhadap Undang-undang Nomor 8 Tahun 2015 tentang Perubahan atas Undang-undang Nomor 1 Tahun 2015 tentang Penetapan Peraturan Pemerintah Pengganti Undangundang Nomor 1 Tahun 2014 tentang Pemilihan Gubernur, Bupati, dan Walikota Menjadi Undang-Undang.

\section{B. Kerangka Teori}

Kerangka teori dalam penelitian hukum sangat diperlukan untuk membuat jenis nilai-nilai oleh postulat-postulat hukum sampai kepada landasan filosofisnya yang

${ }^{5}$ Amiruddin \& Zainal, Pengantar Metode Penelitian Hukum, (Raja Grafindo Persada, Jakarta, 2004), Halaman 119

${ }^{6}$ Peter Mahmud Marzuki, Penelitian Hukum, Cetakan Ke - 5, (Prenada Media Group, Jakarta, 2009), Halaman 96 tertinggi. ${ }^{7}$ Teori hukum sendiri boleh disebut sebagai kelanjutan dari mempelajari hukum positif, setidak-tidaknya dalam urutan yang demikian itulah kita merekonstruksikan kehadiran teori hukum secara jelas. ${ }^{8}$

Teori kedaulatan rakyat muncul pada zaman Renaissance yang mendasarkan hukum pada akal dan rasio. Dasar ini pada abad ke-18 Jeans Jacque Rousseau memperkenalkan teorinya, bahwa dasar terjadinya suatu negara adalah "perjanjian masyarakat" (contract social) yang diadakan oleh dan antara anggota masyarakat untuk mendirikan suatu negara. Adapun teori Jeans Jacque Rousseau tersebut dikemukakannya dalam bukum karangannya yang berjudul $L e$ Contract Social. Teori ini menjadi dasar faham kedaulatan rakyat yang mengajarkan bahwa negara berstandar atas kemauan rakyat, demikian pula halnya semua peraturan-peraturan adalah penjelmaan kemauan rakyat tersebut. 9

Membahas mengenai demokrasi berarti berbicara tentang rakyat atau warga masyarakat. Dalam suatu negara, rakyat merupakan sentral dan sumber kekuasaan, karena pada hakikatnya rakyat adalah pemegang kekuasaan tertinggi, yaitu kedaulatan sedangkan demokrasi merupakan bentuk pengejewantahan dari kedaulatan itu. ${ }^{10}$

Maurice Duverger ${ }^{11}$ menyebutkan bahwa;

"Demokrasi lahir di kota-kota yunani purba atau dalam gerombolan sosial, dimana pemerintahan mengambil wujud demokrasi yang disebut "direk". Kekuasaan dipegang oleh majelis umm rakyat, yang mengambil sendiri semua keputusan penting dan mengangkat para "magistral" yang diberi kewajiban untuk melaksanakan keputusan-

${ }^{7}$ Sacipto Rahardjo, Ilmu Hukum, (Bandung:

PT. Citra Aditya Bakti, 1991), Halaman 254

${ }^{8}$ Ibid. Halaman 253

9 Sudarsono, Pengantar Ilmu Hukum, (Jakarta: PT. Rineka Cipta, 1991), Halaman 110

${ }^{10}$ Nukthoh Arfawie Kurde, Telaah kritis teori Negara Hukum, (Yogyakarta: Pustaka Pelajar, 2005), Halamn 60

${ }^{11}$ Maurice Duverger, Hukum Tata Negara Indonesia, (Surabaya: Pustaka Tinta Mas, 1993), Halaman 10 


keputusan majelis
memerintah dalam waktu antara
sidang-sidang majelis. Sistem
demokrasi ini menurut Duverger
hanya dapat dijadikan dalam
negeri-negeri yang amat kecil
dimana rakyat dengan mudah
dapat dikumpulkan seluruhnya,
sedang hal-hal yang perlu diurus
cukup sederhana untuk dapat
diurus oleh rakyat sendiri."

Suatu negara yang menganut sistem demokrasi dapat dilihat dari ciri-ciri sebagai berikut :12

a. Demokrasi adalah suatu sistem pemerintahan yang mempunyai unsur-unsur atau elemenelemen yang saling terkait dan tidak dapat dipisahkan;

b. Orang-orang yang memegang kekuasaan atas nama demokrasi dapat mengambil keputusan untuk menetapkan dan menegakkan hukum;

Kekuasaan untuk mengatur dalam bentuk aturan hukum tersebut diperoleh dan dipertahankan melalui pemilihan umum yang bebas dan diikuti oleh sebagian besar warga negara dewasa dari suatu negara.

\section{Hasil Dan Pembahasan}

\section{A. Pengertian Pilkada}

Pilkada atau pemilihan kepala daerah merupakan sarana pelaksanaan kedaulatan rakyat di daerah. Hal ini merupakan bagian dari perkembangan sistem penyelenggaraan pemerintahan Negara Republik Indonesia yang mengalami berbagai perubahan. Perubahan yang dimaksud adalah prinsip otonomi yang berarti keleluasaan untuk mengatur daerahnya sendiri pada setiap daerah. Pemilihan kepala daerah (Pilkada) dilakukan secara langsung oleh penduduk daerah administratif setempat yang memenuhi syarat. Pemilihan kepala daerah dilakukan satu paket bersama dengan wakil kepala daerah. Kepala daerah dan wakil kepala daerah yang dimaksud mencakup:

${ }^{12}$ James Mac Gregor Burns dalam Saifudin, Partisipasi Publik Dalam Pembentukan Peraturan Perundang-undangan, (Yogyakarta : FH UII Press, 2009), Halaman 13
1. Gubernur dan wakil gubernur untuk provinsi

2. Bupati dan wakil bupati untuk kabupaten

3. Wali kota dan wakil wali kota untuk kota

\section{B. Pengertian Kepala Daerah}

Pengertian kepala daerah bertumpu pada pengertian yang diberikan secara yuridis dalam hubungannya dengan Pasal 18 ayat (4) UUD 1945 yang menyebutkan bahwa gubernur, bupati, walikota masingmasing sebagai kepala pemerintahan provinsi, kabupaten, dan kota yang dipilih secara demokratis. Selain itu Undang-undang Nomor 9 Tahun 2015 tentang Perubahan Kedua atas Undang-undang Nomor 23 Tahun 2014 tentang Pemerintahan Daerah selaku aturan yang melaksanakan amanah UUD 1945 yang diatur dalam Pasal 18 ayat (4) diatas, dalam Pasal 24 ayat (1) menyatakan setiap daerah dipimpin oleh kepala pemerintahan daerah yang disebut kepala daerah. Di samping itu, Pasal 24 ayat (2) UU No. 9 Tahun 2015 menyebutkan bahwa kepala daerah sebagaimana dimaksud ayat (1) untuk provinsi disebut gubernur, untuk kabupaten disebut bupati, dan untuk kota disebut walikota. ${ }^{13}$

Selanjutnya dalam menentukan tugas dan wewenang kepala daerah yaitu gubernur, bupati, dan walikota, oleh UU No. 9 Tahun 2015, dalam Pasal 25 mengatur bahwa kepala daerah memiliki tugas dan wewenang memimpin penyelenggaraan pemerintahan daerah berdasarkan kebijakan yang ditetapkan bersama DPRD. Dalam Pasal 21 UU No. 9 Tahun 2015 mengatur hak dan kewajiban daerah dalam menyelenggarakan otonomi daerah memakai kata pimpinan dalam ayat (6) yang menyatakan memilih pimpinan daerah.

Kemudian akan dicoba memberikan pengertian apa yang dimaksud dengan daerah. Dalam UUD 1945 Pasal 8 ayat (1) disebutkan, 'Negara Kesatuan Republik Indonesia dibagi atas daerah-daerah provinsi dan daerah provinsi itu dibagi atas kabupaten dan kota yang masing-masing memiliki pemerintahan daerah yang diatur dalam Undang-undang.

Dalam Pasal 1 ayat (6) UU No. 9 Tahun 2015, pengertian daerah otonom,

\section{${ }^{13}$ Ibid}


disebutkan bahwa 'Daerah otonom adalah kesatuan masyarakat hukum yang mempunyai batas-batas wilayah yang berwenang mengatur dan mengurus urusan pemerintahan dan kepentingan masyarakat setempat menurut prakarsa sendiri berdasarkan aspirasi masyarakat dalam sistem Negara Kesatuan Republik Indonesia.

Kemudian apa yang dimaksud dipilih secara demokratis. Dalam Pasal 18 UUD 1945 digunakan kata dipilih secara demokratis. Penggunaan kata tersebut ditafsirkan ke dalam arti gubernur, bupati, walikota dapat dipilih secara perwakilan, yaitu melalui suara terbanyak dalam suatu sidang DPRD dan juga dapat dipilih langsung melalui Pilkada. ${ }^{14}$

Meskipun Pasal 18 ayat (4) memungkinkan dilakukannya pemilihan secara perwakilan, namun pada saat ini telah terbit UU No. 1 Tahun 2015 yang mengatur tentang pemilihan kepala daerah secara langsung untuk seluruh wilayah NKRI sebagaimana dalam Pasal 24 ayat (5) yang menyatakan bahwa kepala daerah dan wakil Kepala daerah sebagaimana dimaksud pada ayat (2) dan ayat (3) dipilih secara langsung oleh rakyat didaerah yang bersangkutan.

Pemilihan secara langsung terhadap kepala daerah dan wakil kepala daerah yang dikenal secara luas dengan istilah 'Pilkada', diselenggarakan oleh suatu badan yang independen yaitu Komisi Pemilihan Umum Daerah (KPUD) yang bertanggung jawab kepada DPRD.

\section{Pelaksanaan Pengawasan Pilkada berdasarkan Undang-undang Nomor 8 Tahun 2015}

Pengawas pilkada memiliki kewenangan menyelesaikan sengketa pemilihan, prosesnya dilakukan dengan mempertemukan para pihak, agar diperoleh kesepakatan melalui musyawarah. Hal ini disebutkan pada Pasal 143 Undang-undang No. 1 Tahun 2015 tentang Penetapan Peraturan Pemerintah Pengganti Undangundang No. 1 Tahun 2014 tentang Pemilihan Gubernur, Bupati dan Wali Kota menjadi Undang-undang sebagaimana telah diubah dengan Undang-undang No. 8 Tahun 2015. Pengawas pilkada yang akan mempertemukan para pihak, pada prinsipnya telah melakukan kajian baik laporan maupun temuan sengketa pemilihan. Dalam mempertemukan para pihak, pengawas pemilu berperan sebagai fasilitator musyawarah, memberikan kesempatan yang sama kepada para pihak menyampaikan permasalahan, tuntutan dan alasan. Jika diperlukan, pengawas pemilu dapat memberikan saran dan masukan kepada para pihak mengenai permasalahan yang disengketakan. ${ }^{15}$

Musyawarah sengketa pemilihan para pihak selama berlangsung, dapat mencapai sepakat maupun tidak mencapai sepakat. Hasil kesepakatan para pihak diperoleh dari musyawarah mufakat dan tidak boleh bertentangan dengan peraturan perundang-undangan. Apabila tercapai kesepakatan, maka pengawas pemilu menuangkan hasil kesepakatan dalam berita acara musyawarah penyelesaian sengketa pemilihan. Tetapi apabila tidak tercapai kesepakatan, maka pengawas pemilu membuat keputusan melalui rapat pleno tertutup, dituangkan dalam keputusan penyelesaian sengketa pemilihan bersifat final dan mengikat. Pada dasarnya, sengketa pemilihan dinyatakan selesai apabila musyawarah telah mencapai mufakat dan pengawas pemilu sudah membuat keputusan bersifat final dan mengikat. Selanjutnya, permohonan penyelesaian sengketa dinyatakan gugur apabila, pemohon dan/atau termohon meninggal dunia, pemohon atau kuasanya tidak datang dan hadir dalam pertemuan pertama setelah tiga kali dilakukan pemanggilan secara patut dan sah oleh pengawas pemilu. Selanjutnya, termohon telah memenuhi tuntutan pemohon sebelum dilaksanakannya proses penyelesaian sengketa pemilihan, pemohon mencabut permohonannya. 16

Sengketa pemilihan merupakan bagian dari pelanggaran pemilihan. Pasal 135 Undang-undang No. 1 Tahun 2015 sebagaimana telah diubah dengan Undangundang No. 8 Tahun 2015, menyebutkan

15 http://www.riaupos.co/3886-opinipenyelesaian-sengketa-pilkada.html\#.V7-

eLuP7LIU\#ixzz4IOou4lv2, diakses tanggal 24 Agustus 2016

${ }^{16}$ Ibid 
laporan pelanggaran pemilihan meliputi pelanggaran kode etik penyelenggara pemilihan diteruskan oleh Bawaslu ke DKPP, adalah pertama, pelanggaran terhadap etika penyelenggara pemilihan yang berpedoman kepada sumpah dan/atau janji sebelum menjalankan tugas sebagai penyelenggara pemilihan. ${ }^{17}$

Kedua, pelanggaran administrasi pemilihan diteruskan kepada KPU, KPU provinsi, atau KPU kabupaten/kota, adalah pelanggaran terhadap tata cara yang berkaitan dengan administrasi pelaksanaan pemilihan dalam setiap tahapan pemilihan. Ketiga, sengketa pemilihan diselesaikan oleh Bawaslu. Keempat, tindak pidana pemilihan ditindaklanjuti oleh Kepolisian Negara RI, adalah pelanggaran atau kejahatan terhadap ketentuan pemilihan. Pelanggaran pemilihan yang telah disebutkan di atas, baik temuan pengawas pemilu maupun laporan masyarakat, samasama melalui proses kajian. Perbedaan hanya tampak pada mekanisme penyelesaian atau penanganan pelanggaran. Jika sengketa ditempuh melalui musyawarah mufakat, maka pelanggaran lainnya (kode etik, administrasi dan tindak pidana pemilihan) dilakukan klarifikasi meminta keterangan dari pelapor dan terlapor. Selepas klarifikasi meminta keterangan, pengawas pemilu melakukan kajian dugaan pelanggaran, kemudian mengeluarkan surat penerusan dan status laporan. ${ }^{18}$

\section{Tugas Dan Fungsi Badan Pengawas Pemilihan Umum dalam Penyelenggaraan Pilkada}

Badan Pengawas Pemilihan Umum (disingka tBawaslu) adalah lembaga penyelenggara Pemilu yang bertugas mengawasi penyelenggaraan Pemilu di seluruh wilayah Negara Kesatuan Republik Indonesia. Bawaslu diatur dalam Bab IV Undang-undang Nomor 15 Tahun 2011 tentang Penyelenggara Pemilihan Umum. Jumlah anggota Bawaslu sebanyak 5 (lima) orang. Keanggotaan Bawaslu terdiri atas kalangan professional yang mempunyai kemampuan dalam melakukan pengawasan

${ }^{17}$ Ibid
${ }^{18}$ Ibid

dan tidak menjadi anggota partai politik. Dalam melaksanakan tugasnya anggota Bawaslu didukung oleh Sekretariat Jenderal Badan Pengawas Pemilihan Umum. ${ }^{19}$

Tugas dan fungsi Bawaslu Berdasarkan Undang-undang Nomor 15 Tahun 2011 tentang Penyelenggaraan Pemilu adalah :20

1. Bawaslu menyusun standar tata laksana kerja pengawasan tahapan penyelenggaraan Pemilu sebagai pedoman kerja bagi pengawas Pemilu di setiap tingkatan.

2. Bawaslu bertugas mengawasi penyelenggaraan Pemilu dalam rangka pencegahan dan penindakan pelanggaran untuk terwujudnya Pemilu yang demokratis yang meliputi:

\section{a. mengawasi penyelenggaraan Pemilu yang terdiri atas:}

1. perencanaan dan penetapan jadwal tahapan Pemilu;

2. perencanaan pengadaan logistik oleh KPU;

3. pelaksanaan penetapan daerah pemilihan dan jumlah kursi pada setiap daerah pemilihan untuk pemilihan anggota Dewan Perwakilan Rakyat Daerah Provinsi dan anggota Dewan Perwakilan Rakyat Daerah Kabupaten/Kota oleh KPU sesuai dengan ketentuan peraturan perundang-undangan;

4. sosialisasi penyelenggaraan Pemilu; dan

5. pelaksanaan tugas pengawasan lain yang diatur dalam ketentuan peraturan perundang-undangan.

b. mengawasi pelaksanaan tahapan penyelenggaraan Pemilu yang terdiri atas:

1. pemutakhiran data pemilih dan penetapan daftar pemilih sementara serta daftar pemilih tetap;

2. penetapan peserta Pemilu;

3. proses pencalonan sampai dengan penetapan anggota Dewan Perwakilan Rakyat, Dewan Perwakilan Daerah, Dewan Perwakilan Rakyat Daerah,

${ }^{19}$ https://id.wikipedia.org/wiki/Badan_Peng awas_Pemilihan Umum\#Badan_Pengawas_Pemilu Provinsi, diakses tanggal 24 Agustus 2016

${ }^{20}$ Ibid 
pasangan calon presiden dan wakil presiden, dan calon gubernur, bupati, dan walikota sesuai dengan ketentuan peraturan perundang-undangan;

4. pelaksanaan kampanye;

5. pengadaan logistik Pemilu dan pendistribusiannya;

6. pelaksanaan pemungutan suara dan penghitungan suara hasil Pemilu di TPS;

7. pergerakan surat suara, berita acara penghitungan suara, dan sertifikat hasil penghitungan suara dari tingkat TPS sampai ke PPK;

8. pergerakan surat tabulasi penghitungan suara dari tingkat TPS sampai ke KPU Kabupaten/Kota;

9. proses rekapitulasi hasil penghitungan perolehan suara di PPS, PPK, KPU Kabupaten/Kota, KPU Provinsi, dan KPU;

10. pelaksanaan penghitungan dan pemungutan suara ulang, Pemilu lanjutan, dan Pemilu susulan;

11. pelaksanaan putusan pengadilan terkait dengan Pemilu;

12. pelaksanaan putusan DKPP; dan

13. proses penetapan hasil Pemilu.

c. mengelola, memelihara, dan merawat arsip/dokumen serta melaksanakan penyusutannya berdasarkan jadwal retensi arsip yang disusun oleh Bawaslu dan ANRI;

d. memantau atas pelaksanaan tindak lanjut penanganan pelanggaran pidana Pemilu oleh instansi yang berwenang;

e. mengawasi atas pelaksanaan putusan pelanggaran Pemilu;

f. evaluasi pengawasan Pemilu;

g. menyusun laporan hasil pengawasan penyelenggaraan Pemilu; dan

h. melaksanakan tugas lain yang diatur dalam ketentuan peraturan perundang-undangan.

3. Dalam melaksanakan tugas, Bawaslu berwenang:

a. menerima laporan dugaan pelanggaran terhadap pelaksanaan ketentuan peraturan perundangundangan mengenai Pemilu;

b. menerima laporan adanya dugaan pelanggaran administrasi Pemilu dan mengkaji laporan dan temuan, serta merekomendasikannya kepada yang berwenang;

c. menyelesaikan sengketa Pemilu;

d. membentuk Bawaslu Provinsi;

e. mengangkat dan memberhentikan anggota Bawaslu Provinsi; dan

f. melaksanakan wewenang lain yang diatur dalam ketentuan peraturan perundang-undangan.

4. Bawaslu berkewajiban:

a. bersikap tidak diskriminatif dalam menjalankan tugas dan wewenangnya;

b. melakukan pembinaan dan pengawasan terhadap pelaksanaan tugas Pengawas Pemilu pada semua tingkatan;

c. menerima dan menindaklanjuti laporan yang berkaitan dengan dugaan adanya pelanggaran terhadap pelaksanaan peraturan perundang-undangan mengenai Pemilu;

d. menyampaikan laporan hasil pengawasan kepada Presiden, Dewan Perwakilan Rakyat, dan KPU sesuai dengan tahapan Pemilu secara periodik dan/atau berdasarkan kebutuhan; dan

e. melaksanakan kewajiban lain yang diberikan oleh peraturan perundang-undangan

\section{PENUTUP}

A. Kesimpulan

1. Pengawas pilkada memiliki kewenangan menyelesaikan sengketa pemilihan, prosesnya dilakukan dengan mempertemukan para pihak, agar diperoleh kesepakatan melalui musyawarah. Hal ini disebutkan pada Pasal 143 Undang-Undang No. 1 Tahun 2015 tentang Penetapan Peraturan Pemerintah Pengganti Undang-Undang No. 1 Tahun 2014 tentang Pemilihan Gubernur, Bupati dan Wali Kota menjadi Undang-undang sebagaimana telah diubah 
dengan Undang-undang No. 8 Tahun 2015. Pengawas pilkada yang akan mempertemukan para pihak, pada prinsipnya telah melakukan kajian baik laporan maupun temuan sengketa pemilihan. Dalam mempertemukan para pihak, pengawas pemilu berperan sebagai fasilitator musyawarah, memberikan kesempatan yang sama kepada para pihak menyampaikan permasalahan, tuntutan dan alasan. Jika diperlukan, pengawas pemilu dapat memberikan saran dan masukan kepada para pihak mengenai permasalahan yang disengketakan.

2. Badan Pengawas Pemilihan Umum (disingkat Bawaslu) adalah lembaga penyelenggara Pemilu yang bertugas mengawasi penyelenggaraan Pemilu di seluruh wilayah Negara Kesatuan Republik Indonesia. Bawaslu diatur dalam bab IV UndangUndang Nomor 15 Tahun 2011 tentang Penyelenggara Pemilihan Umum.

\section{B. Saran}

1. Pengawas pilkada harus dapat menjadi penyeimbang dalam pelaksanaan pilkada agar terselenggaranya pilkada yang jujur dan adil.

2. Bawaslu harus lebih pro aktif dalam pengawasan pilkada, jangan hanya bertindak apa bila mendapatkan laporan dari masyarakat

\section{DAFTAR PUSTAKA}

\section{A. Buku}

Amiruddin \& Zainal, 2004, Pengantar Metode Penelitian Hukum, Jakarta, Raja Grafindo Persada.

Widodo, H., 2016, Hukum Acara Perselisihan Hasil Pilkada Serentak Di Mahkamah Konstitusi, Jakarta, Sinar Grafika.
Duverger, M., 1993, Hukum Tata Negara Indonesia, Surabaya: Pustaka Tinta Mas.

Kurde, N.A., 2005, Telaah kritis teori Negara Hukum, Yogyakarta: Pustaka Pelajar.

Marzuki, P.M., 2009, Penelitian Hukum, Cetakan Ke - 5, Jakarta, Prenada Media Group.

Rahardjo, S., 1991, Ilmu Hukum, Bandung: PT. Citra Aditya Bakti.

Sudarsono, 1991, Pengantar Ilmu Hukum, Jakarta: PT. Rineka Cipta

Suharyanto, A, (2014). Partisipasi Politik Masyarakat Tionghoa dalam Pemilihan Kepala Daerah, Jurnal Ilmu Pemerintahan dan Sosial Politik, 2 (2): 166-175

B. Peraturan Perundang Undangan

Undang-Undang Dasar Negara Republik Indonesia Tahun 1945.

Undang-Undang Nomor 15 Tahun 2011 tentang Penyelenggara Pemilihan Umum.

Undang-Undang Nomor 8 Tahun 2015 tentangPerubahan Atas UndangUndang Nomor 1 Tahun 2015 tentang Penetapan Peraturan Pemerintah Pengganti Undang-Undang Nomor 1 Tahun 2014 tentang Pemilihan Gubernur, Bupati, dan Walikota Menjadi Undang-Undang

\section{Internet \\ http://www.riaupos.co/3886-opini- penyelesaian-sengketa- pilkada.html\#.V7- eLuP7LIU\#ixzz4IOou4lv2, diakses tanggal 24 Agustus 2016 \\ https://id.wikipedia.org/wiki/Badan Pengaw as Pemilihan_Umum\#Badan_Penga was_Pemilu_Provinsi diakses tanggal 24 Agustus 2016}

